UDC 544.653.2

\author{
T. Luk'yanenko, O. Shmychkova, V. Knysh, A. Velichenko
}

\title{
DESIGN AND PROPERTIES OF DIMENSIONALLY STABLE ANODES ON EBONEX` SUBSTRATE
}

\author{
Ukrainian State University of Chemical Technology, Dnipro, Ukraine
}

\begin{abstract}
Ceramic materials consisting of Magneli phases (titanium «suboxides» and having the general formula $\mathrm{Ti}_{\mathrm{n}} \mathrm{O}_{2 \mathrm{n}-1}$, where $\mathrm{n}=4-10$ ), commercially recognized under the Ebonex ${ }^{\circledR}$ trade name, were used as substrates for designing of dimensionally stable anodes. The non-continuous platinum transition layer $\left(2 \mathrm{mg} \mathrm{Pt}\right.$ per $\left.\mathrm{cm}^{2}\right)$ was formed before deposition of the resulting coating by electrochemical-pyrolytic method. The chemical and phase composition of the resulting layer and its physicochemical properties were investigated. According to the data obtained, the main phase of the commercial Ebonex ${ }^{\circledast} \operatorname{is~} \operatorname{Ti}_{6} \mathrm{O}_{11}$. The system begins to collect oxygen during the thermal treatment due to oxidation of the suboxides with the air oxygen. Hollandite is one of the phases appeared already at $230^{\circ} \mathrm{C}$, it splits into two phases, $\mathrm{Ti}_{5} \mathrm{O}_{9}$ and $\mathrm{TiO}_{2}$, during the treatment. The transformation of the system continues with a subsequent increase in the temperature and a new phase of titanium oxide appears at $310^{\circ} \mathrm{C}$ instead of $\mathrm{Ti}_{5} \mathrm{O}_{9}$. This phase was identified for the first time. The amount of oxygen in the system increases at $410^{\circ} \mathrm{C}$, which leads to the additional appearance of $\mathrm{TiO}_{2}$ in the form of rutile. It has been shown that the service life of dimensionally stable anodes is largely determined by the nature of the substrate and the temperature of the formation of a transition layer. The maximum lifetime of the anodes was observed for the substrates treated at $410^{\circ} \mathrm{C}$. At the same time, the maximum service life of the anode at $500 \mathrm{~mA} \mathrm{~cm}{ }^{-2}$ was 325 hours with an active coating of $\mathrm{PbO}_{2}-\mathrm{TiO}_{2}$, which exceeds the common $\mathrm{PbO}_{2}$ system by 16 times.
\end{abstract}

Keywords: Ebonex ${ }^{\circledR}$, substrate, transition layer, dimensionally stable anodes, service life.

DOI: $10.32434 / 0321-4095-2019-127-6-121-127$

Ebonex $^{\circledast}$ is a trade name of an electrically conductive ceramic suboxide of titanium, having the approximate composition $\mathrm{Ti}_{4} \mathrm{O}_{7}$ and conductivity comparable to that of carbon [1]. Ebonex powder can be sintered into a variety of shapes and porosities [2]. Such materials are recognized to be of considerable interest in their use as substrates for creating of dimensionally stable anodes (DSA) because of high electrical conductivity and satisfactory mechanical properties [2,3]. However, Ebonex ${ }^{\circledR}$ itself has a number of disadvantages that make it unnecessary to use it unalterably due to the propensity for passivation by anodic polarization because of increasing the amount of oxygen to the stoichiometric value, which results in the formation of titanium(IV) oxide over time. The latter is n-type semiconductor with low carrier content. Hence, DSA with a substrate of this type will fail not only due to mechanical destruction of the catalyst active layer, but also because of the significant increase in the anode potential due to the passivation of the substrate. To overcome these disadvantages, the creation of a transition layer between Ebonex ${ }^{\circledR}$ and an active coating is required; for example, by the application of a thin layer of platinum group metals that will be used as donor carriers in the semiconductor and prevent the passivation of the substrate [4-6]. In this case, it is possible to use temperature and treatment time in the oxygen-containing atmosphere as additional parameters that influence the composition and properties of the transition layer.

\section{Material and methods}

All chemicals were reagent grade. Monolithic block of Ebone $\mathrm{x}^{\circledR}$ (density of $8.5 \mathrm{~g} \mathrm{~cm}^{-3}$ and porosity of 12-18 vol.\%), supplied by Atraverda Ltd, was cut with diamond-cutter in $10 \mathrm{~mm} \times 10 \mathrm{~mm}$ square samples. These samples were used as substrate in this work. Ebonex ${ }^{\circledR}$ was treated before platinum 
electrodeposition in the following way: (i) polishing by moist abrasive paper and rinsing; (ii) chemical etching in $0.5 \mathrm{M} \mathrm{HCl}+0.1 \mathrm{M} \mathrm{CH}_{3} \mathrm{COOH}+0.02 \mathrm{M}$ $\mathrm{NaF}$ solution at $50^{\circ} \mathrm{C}$ for $60 \mathrm{~min}$; and (iii) rinsing and ultrasonically treating in water to remove remains of etchant from the Ebonex ${ }^{\circledR}$ pores. After that, platinum was electrodeposited at $80^{\circ} \mathrm{C}$ at a cathode current density of $20 \mathrm{~mA} \mathrm{~cm} \mathrm{~cm}^{-2}$ from solution containing $0.05 \mathrm{M} \mathrm{K}_{2} \mathrm{PtCl}_{6}+1.5 \mathrm{M} \mathrm{NaNO}_{2}+100 \mathrm{~g} \mathrm{~L}^{-1}$; $10 \mathrm{M} \mathrm{NH}_{3}$ [7]. The coating thickness was about $1 \mu \mathrm{m}\left(\sim 2 \mathrm{mg} \mathrm{cm}^{-2} \mathrm{Pt}\right)$. Some initial and platinized samples were thermally treated in the air using tube furnace at 230,310 or $410^{\circ} \mathrm{C}$ for 1 hour. Electrochemical measurements were carried out in $1 \mathrm{M} \mathrm{HClO}_{4}$ solution with GAMRY Potentiostat/ Galvanostat/ZRA Reference 3000 in a standard temperature-controlled three-electrode cell with $\mathrm{Pt}$ auxiliary electrode. All potentials were recorded and reported versus $\mathrm{Ag} / \mathrm{AgCl} / \mathrm{KCl}$ (sat.) reference electrode. The temperature was $25 \pm 1^{\circ} \mathrm{C}$.

Surface morphology was studied by scanning

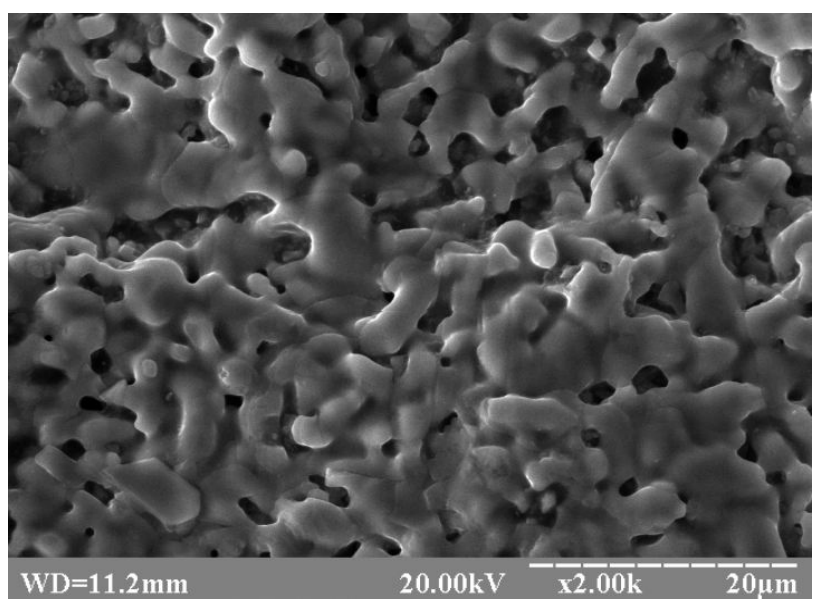

a

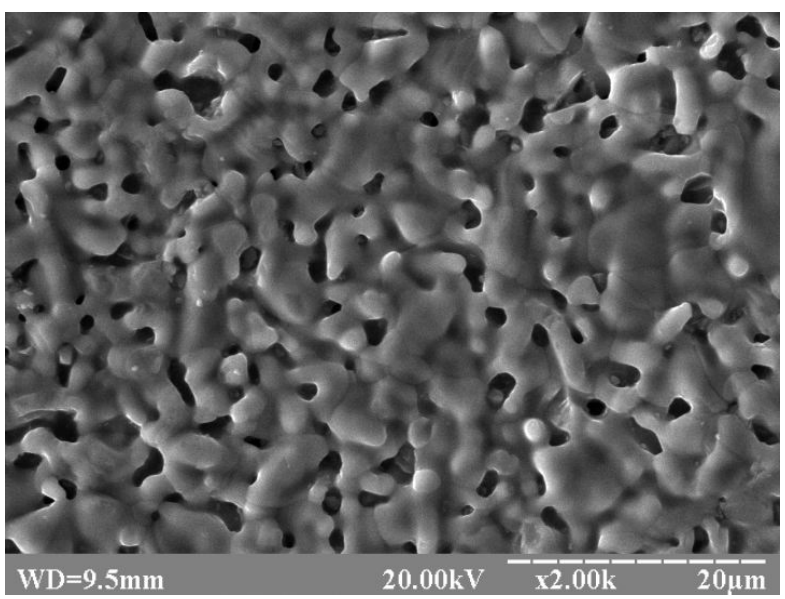

c electron microscopy (SEM) technique using a REM-106I microscope. Phase analysis was performed using $\mathrm{X}$-ray powder diffraction (DRON-2.0 M with FeK-radiation, Bragg-Brentano geometry, $\theta / 2 \theta$-scanning, $10.000 \leq 2 \theta \leq 125.000$ range with scanning step $0.050^{\circ} 2^{0}$ and $3^{0} \mathrm{~s}$ exposure time). The observed diffraction intensities were compared with reference powder patterns of binary and known ternary phases using PowderCell and STOE WinXPOW program packages. The crystal structure refinement was performed using the Rietveld method. Calculations of the unit cell parameters and theoretical patterns were performed using WinPLOTR program packages.

\section{Results and discussion}

In the first place, we consider the influence of the conditions of the formation of transition layers on the surface morphology and their phase composition. As follows from Fig. 1, the initial Ebone ${ }^{\otimes}$ has a morphology that is typical of materials obtained from powders by sintering in an inert or

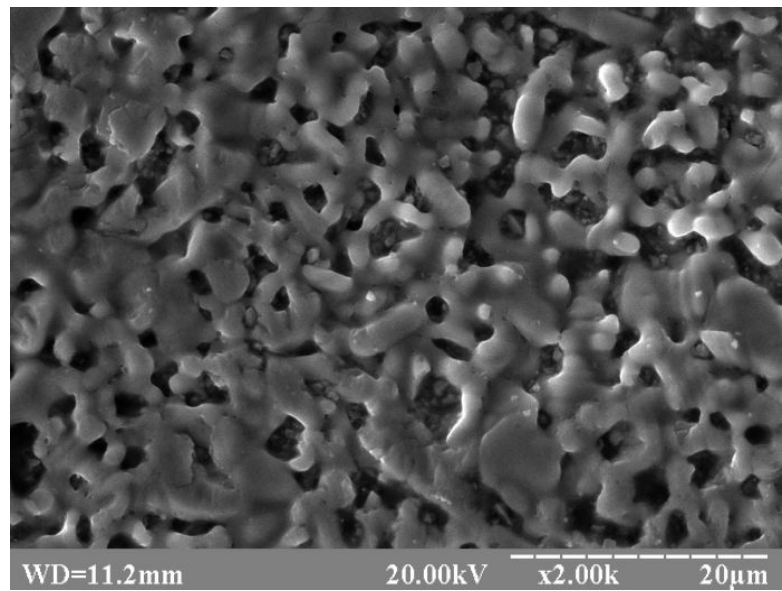

b

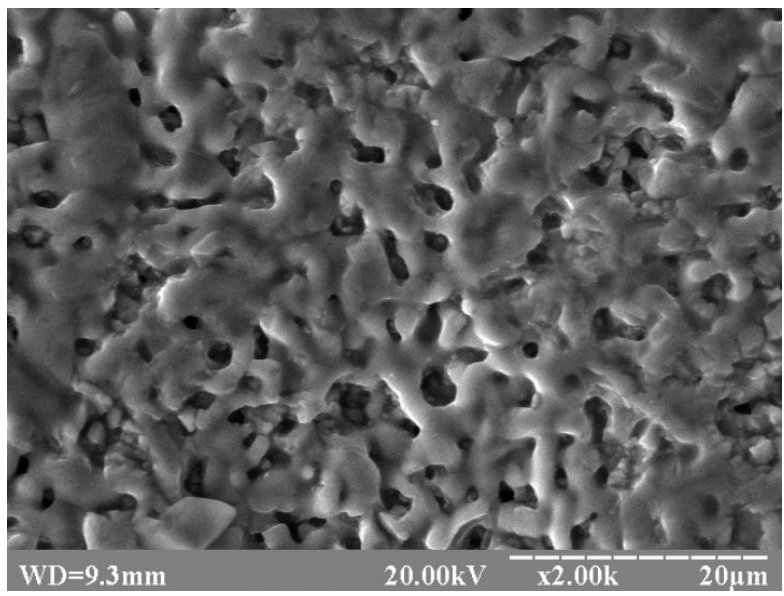

d

Fig. 1. SEM-images of Ebonex ${ }^{\circledast}$ surface (a), heat treated for 1 hour at $230^{\circ} \mathrm{C}(\mathrm{b}) ; 310^{\circ} \mathrm{C}$ (c) and $410^{\circ} \mathrm{C}(\mathrm{d})$ 
reducing atmosphere and characterized by a sufficiently developed porous surface [2]. As the temperature rises, a gradual destruction of melting amorphous zones with the appearance of chaotically oriented small crystals is observed. This is also facilitated by an increase in the duration of the heat treatment.

The observed differences in morphology are due to both the change in the chemical and the phase composition of titanium oxides due to their oxidation with oxygen. At the same time, the observed changes are rather slow due to the relatively low partial pressure of oxygen and slight diffusion rates in the solid phase.

As follows from the obtained results, when $2 \mathrm{mg} \mathrm{cm}{ }^{-2}$ of platinum is electrochemically deposited on the surface of Ebonex ${ }^{\circledR}$, the metal coating is not continuous and is appeared as separate islands with a weak crystallinity. The thermal treatment of the coating leads to a change in its morphology, which differs from Ebonex $^{\circledR}$ only by the presence of platinum-like crystals melted on the substrate. These data are confirmed by SEM images and discussed in detail elsewhere [8]. The obtained results indicate not only the possibility of thermodiffusion of the metal, but also its chemical interaction with both air oxygen and titanium oxides.

$\mathrm{Ti}_{4} \mathrm{O}_{7}$ is one of a wide range of defined compositions $\mathrm{TiO}_{\mathrm{x}}(0.5<\mathrm{x}<2)$; those between that of Ebonex $(x=1.75)$ and $x=1.9$ have a triclinic crystal structure and are known as Magneli phases $\mathrm{Ti}_{n} \mathrm{O}_{2 \mathrm{n}-1}$ [1].

Usually, $\mathrm{Ti}_{4} \mathrm{O}_{7}, \mathrm{Ti}_{5} \mathrm{O}_{9}$ and $\mathrm{Ti}_{6} \mathrm{O}_{11}$ are the main forms of titanium suboxides that are represented in the Ebonex $^{\circledR}[9,10]$. From the crystallochemical point of view, the triclinic symmetry and a similar metric of unit cells are similar to them. According to the data obtained, $\mathrm{Ti}_{6} \mathrm{O}_{11}$ is the main phase of the commercial Ebonex ${ }^{\circledast}$. The system begins to collect oxygen during the thermal treatment due to oxidation of the suboxides with the air oxygen. Already at $230^{\circ} \mathrm{C}$, hollandite appeared as one of the phases, that is a hydrated form of titanium(IV) oxide in the form of $\mathrm{TiO}_{2}(\mathrm{H})$ [8], which facilitates lattice diffusion of cations [11,12]. This polymorphic form contains a double chain of octahedral $\mathrm{TiO}_{6}$ forming $(2 \times 2)$ tunnels. $\mathrm{Ti}_{6} \mathrm{O}_{11}$ phase split into two, $\mathrm{Ti}_{5} \mathrm{O}_{9}$ and $\mathrm{TiO}_{2}$, during the heat treatment because of a low rate of oxygen diffusion in the solid phase. In this regard, more thermodynamically stable titanium(IV) oxide picks up oxygen from the $\mathrm{Ti}_{6} \mathrm{O}_{11}$ phase. The transformation of the system continues with a subsequent increase in the temperature at a fixed time of the treatment. At $310^{\circ} \mathrm{C}$, a new phase of titanium oxide appears instead of $\mathrm{Ti}_{5} \mathrm{O}_{9}$. This phase was identified for the first time [8]. At $410^{\circ} \mathrm{C}$, the amount of oxygen in the system increases which leads to the additional appearance of $\mathrm{TiO}_{2}$ in the form of rutile. At the same time, an increase in the treatment time leads to the complete disappearance of $\mathrm{Ti}_{5} \mathrm{O}_{9}$ phase. Thus, the temperature and processing time of Ebonex ${ }^{\circledast}$ significantly affects the phase composition of the system.

As follows from the data obtained (Fig. 2), the degree of crystallinity of the platinum phase grain increases with increasing temperature and time of treatment. Indeed, there is a shift from the semiamorphous halo of the samples without any heat treatment to satisfactorily formed reflexes of the materials obtained at $410^{\circ} \mathrm{C}$. The lattice parameter of the face-centered cubic (fcc) lattice of platinum as a phase coating is equal to a $3.90 \AA$, which is slightly less than for pure platinum $(a=3.9236 \AA)$. Accurate determination of the unit cell parameter of $\mathrm{Pt}$ in the coating is complicated due to intense reflections of Ebonex ${ }^{\circledast}$ phases [8].

As follows from the results given in Table 1, the size of grains and the lattice parameters of the platinum phase significantly increase with an increase in both the temperature and the treatment time, approaching the pure platinum $(\mathrm{a}=3.9236 \AA)\left(410^{\circ} \mathrm{C}\right.$, 4 hours). At the same time, the internal stresses of the metal coating are substantially reduced (practically by 4 times), which can significantly improve the mechanical stability of the resulting sublayer. The latter is especially important, since one of the main problems of oxide-metal coatings is the shear stress, resulted in the rapid mechanical destruction of the active layer of DSA and, as a result, the low lifetime of such electrodes.

$\mathrm{X}$-ray diffractograms of Ebonex ${ }^{\circledR}$ treated at $310^{\circ} \mathrm{C}$ show an unidentified phase reflection at $\sim 14.80^{\circ} 2 \theta$ (in fact, the only one maximum peak), which does not disappear even in the samples of Ebonex $^{\circledast} / \mathrm{Pt}$ [13], but has minor intensity. The reflection of unknown phase is clearly visional in the diffraction curve obtained for the sample with $2 \mathrm{mg} \mathrm{cm}^{-2} \mathrm{Pt}$, treated at $410^{\circ} \mathrm{C}\left(2 \theta\left(^{0}\right) / \mathrm{d}(\AA): 17.70 /\right.$ $6.292 ; 26.60 / 4.208 ; 30.63 / 3.665$ and the maximum reflection at $35.59 / 3.168$ ). Unfortunately, this phase also failed to identify by the probable variants of known compounds. Perhaps, this is an unknown 


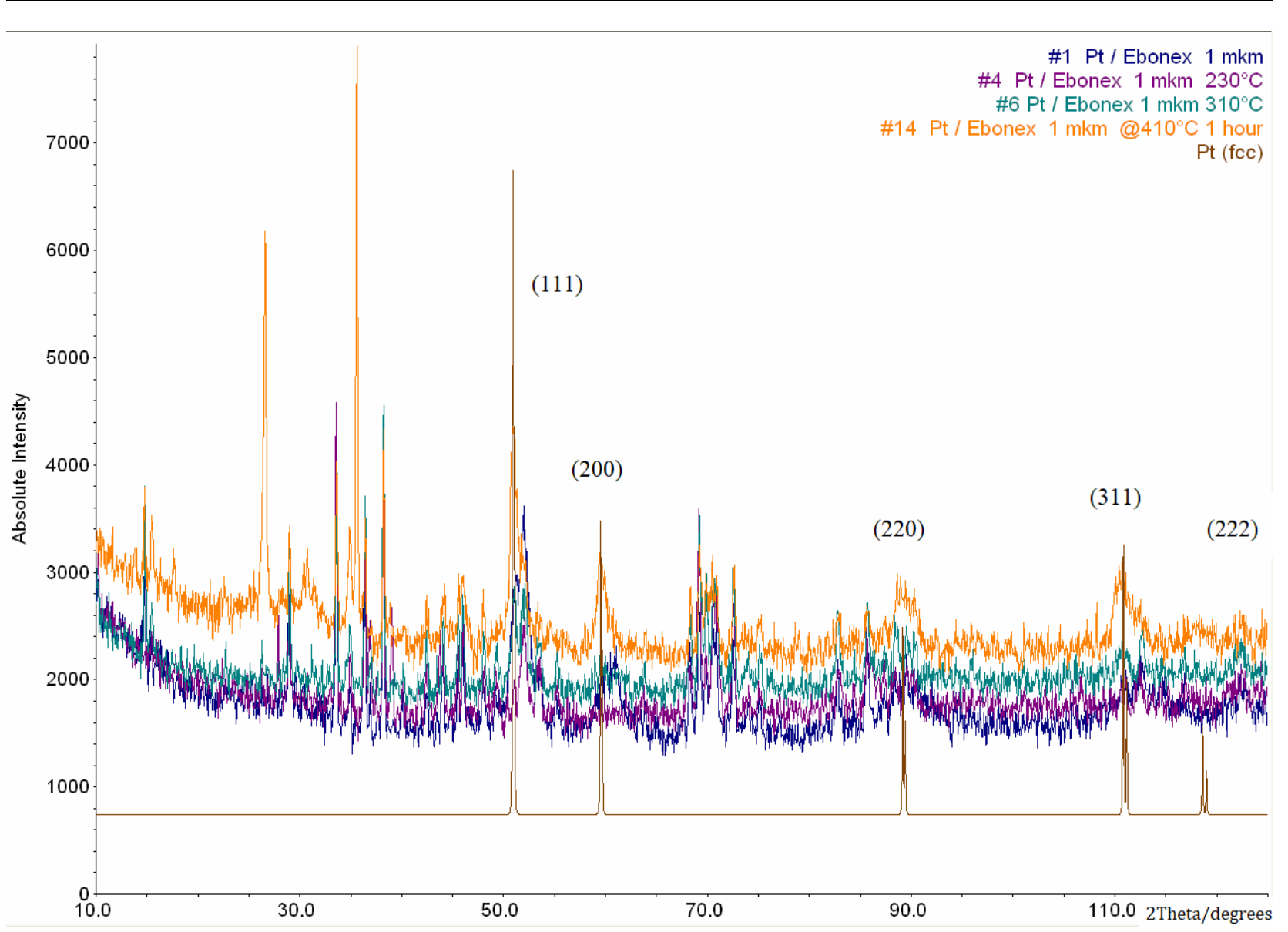

Fig. 2. Diffractograms of Pt (fcc, structural type of copper, spatial group Fm-3m, a $3.90 \AA$ ) and Ebonex ${ }^{\circledast} / \mathrm{Pt}$ samples

Microstructure characteristics and lattice parameter of platinum (space group Fm-3m, Pearson symbol cf4, structural type $\mathrm{Cu}$ ) as a component of Ebonex $\%$ Pt coating

\begin{tabular}{|c|c|c|c|}
\hline Sample & $\begin{array}{c}\text { Lattice parameter a } \\
(\AA)\end{array}$ & $\begin{array}{c}\text { Coherent scattering domain } \\
\text { size }(\AA)^{1}\end{array}$ & $\begin{array}{l}\text { Average maximum internal } \\
\text { stress }(\%)^{2}\end{array}$ \\
\hline Ebonex $^{\circledR} / \mathrm{Pt}$ & $3.840(3)$ & $47 \pm 23$ & $198(70)$ \\
\hline Ebonex $^{\circledR} / \mathrm{Pt}, 230^{\circ} \mathrm{C}, 1 \mathrm{hr}$ & $3.842(4)$ & $46 \pm 24$ & $207(77)$ \\
\hline Ebonex $^{\circledR} / \mathrm{Pt}, 310^{\circ} \mathrm{C}, 1 \mathrm{hr}$ & $3.854(8)$ & $53 \pm 19$ & 161(49) \\
\hline Ebonex $^{\circledR} / \mathrm{Pt}, 410^{\circ} \mathrm{C}, 1 \mathrm{hr}$ & $3.898(3)$ & $67 \pm 16$ & $116(5)$ \\
\hline Ebonex $^{\circledR} / \mathrm{Pt}, 410^{\circ} \mathrm{C}, 4 \mathrm{hrs}$ & $3.9111(17)$ & $154 \pm 26$ & $51(8)$ \\
\hline
\end{tabular}

Note: ${ }^{-}$First approximation - the average grain size of the phase; ${ }^{2}-$ i.e. deformation (microstresses in the crystal lattice).

previously phase of the $\mathrm{Pt}-\mathrm{Ti}-\mathrm{O}$ system [8]. At the same time, the internal stresses of the coating are reduced by almost 4 times.

The application of a platinum layer on Ebonex ${ }^{\circledR}$ leads to an increase in the activity of the electrode, which is revealed by the current growth and the decrease of electrochemical processes overvoltage. The thermal treatment of electrodes does not show any influence on the oxygen overpotential, since metallic platinum remains electrochemically active in all cases.
Prepared Ebonex ${ }^{\circledast} / \mathrm{Pt}$ samples were used as substrates in designing of DSA based on lead dioxide. Since, the fabrication of coatings with a thickness higher than 100 microns is impossible in nitrate solutions due to limitations on the mechanical strength, we proposed to use methanesulfonate electrolytes for $\mathrm{PbO}_{2}$ electrosynthesis [13], in which $\mathrm{PbO}_{2}$ composite coatings can be prepared up to 2 $\mathrm{mm}$ thick with satisfactory mechanical properties [14].

Firstly, $\mathrm{PbO}_{2}$ was electrodeposited on initial 
Ebonex $^{\circledR}$ substrate from $0.1 \mathrm{M} \mathrm{Pb}\left(\mathrm{CH}_{3} \mathrm{SO}_{3}\right)_{2}+0.1 \mathrm{M}$ $\mathrm{CH}_{3} \mathrm{SO}_{3} \mathrm{H}$ solution at $\mathrm{j}_{\mathrm{a}}=10 \mathrm{~mA} \mathrm{~cm}{ }^{-2}$. High-quality lead dioxide coatings with a thickness of up to $2 \mathrm{~mm}$ were deposited with $100 \%$ current efficiency. The coatings have good plasticity and adhesion to the substrate. Nevertheless, the obtained data indicate an extremely low lifetime of these anodes: only a few hours under accelerated tests at anode current density of $500 \mathrm{~mA} \mathrm{~cm}{ }^{-2}$ (Fig. 3, curve 1). The application of platinum transition layer $\left(2 \mathrm{mg} \mathrm{cm}^{-2}\right.$ $\mathrm{Pt})$ on the Ebonex ${ }^{\circledR}$ surface practically does not affect the lifetime of anodes, although there is some decrease in the electrode potential during anodic polarization (Fig. 3, curve 2).

A sharp increase in the potential is observed with the complete disintegration of the lead dioxide coating from the substrate. Ebonex ${ }^{\circledR}$ itself, including that coated with a non-uniform platinum layer, is readily passivated at high anode current densities. The observed effect is associated with the strong heating of Ebonex ${ }^{\circledR}$ at high current densities due to its rather low conductivity, which causes cracking and full detachment of the lead(IV) oxide under accelerated resource tests. However, such electrodes can be operated for hundreds of hours at stable potential and without noticeable mechanical destruction of the active coating at anode current densities of not more than $100 \mathrm{~mA} \mathrm{~cm}{ }^{-2}$.

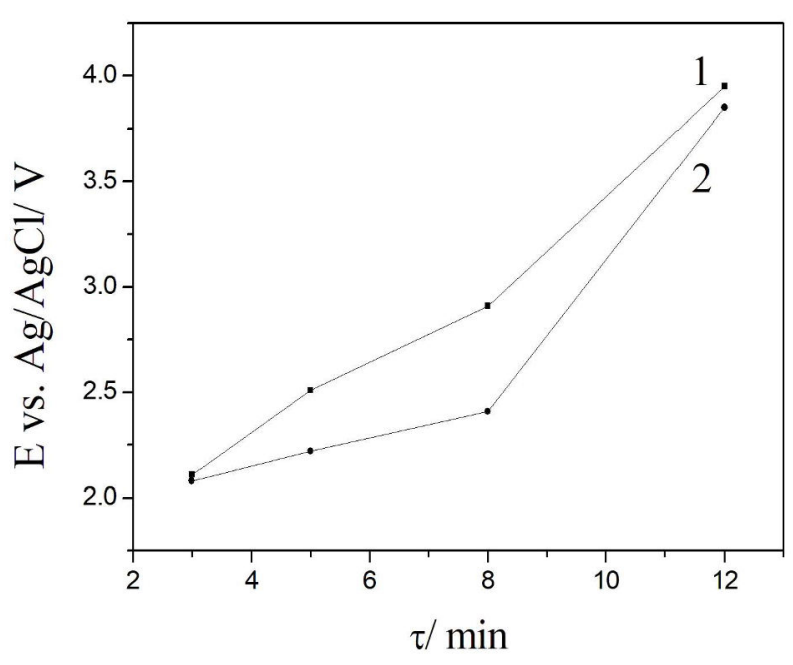

Fig. 3. Potential vs. the polarization time at $500 \mathrm{~mA} \mathrm{~cm}^{-2}$ in $1 \mathrm{M} \mathrm{H}_{2} \mathrm{SO}_{4}$ for $\mathrm{PbO}_{2}$-electrodes obtained from $0.1 \mathrm{M}$ $\mathrm{Pb}\left(\mathrm{CH}_{3} \mathrm{SO}_{3}\right)_{2}+0.1 \mathrm{M} \mathrm{CH}_{3} \mathrm{SO}_{3} \mathrm{H}$ solution on Ebonex ${ }^{\circledast}$ (1) and Ebonex $^{\circledR} /$ Pt substrates

As follows from the data obtained (Fig. 4), the use of a transition platinum layer obtained by the combined electrochemical-pyrolytic method can significantly increase the lifetime of the anodes. The service lifetime of the anodes increases as the temperature of the treatment rises (Fig. 4). A maximum service life of anodes is observed when a transition layer is formed at $410^{\circ} \mathrm{C}$, which is about 105 hours compared to 8 hours for Ebonex ${ }^{\circledR}$ and 20 hours for the common $\mathrm{PbO}_{2}$ coating deposited on $\mathrm{Ti} / \mathrm{Pt}$ substrate [15], that is, an increase in the service life of 12 and 5 times, respectively.

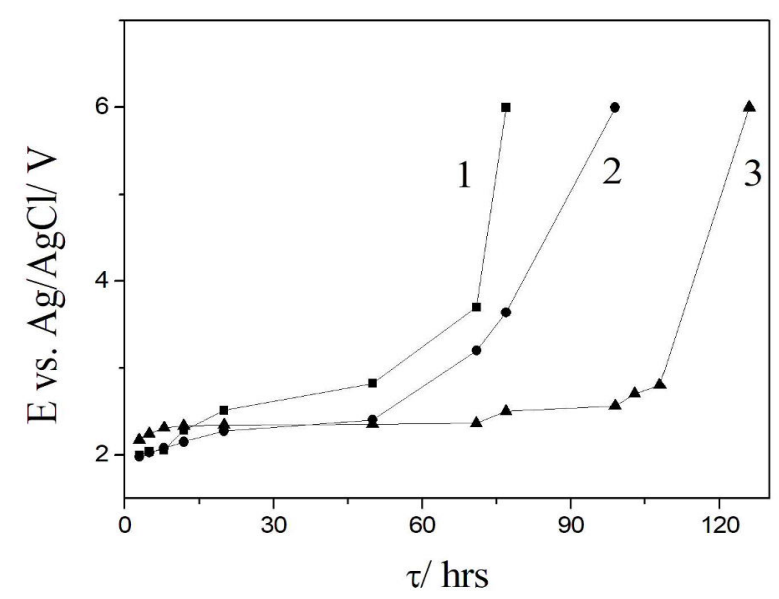

Fig. 4. Potential vs. the polarization time at $500 \mathrm{~mA} \mathrm{~cm}^{-2}$ in $1 \mathrm{M} \mathrm{H}_{2} \mathrm{SO}_{4}$ for $\mathrm{PbO}_{2}$-electrodes obtained from $0.1 \mathrm{M}$ $\mathrm{Pb}\left(\mathrm{CH}_{3} \mathrm{SO}_{3}\right)_{2}+0.1 \mathrm{M} \mathrm{CH}_{3} \mathrm{SO}_{3} \mathrm{H}$ solution on Ebonex ${ }^{\circledast} / \mathrm{Pt}$ $\left(230^{\circ} \mathrm{C}\right)(1)$; Ebonex ${ }^{\circledast} / \mathrm{Pt}\left(310^{\circ} \mathrm{C}\right)(2)$; and Ebonex ${ }^{\circledast} / \mathrm{Pt}\left(410^{\circ} \mathrm{C}\right)$ (3) substrates

It should be noted that the use of an active coating of $\mathrm{PbO}_{2}-\mathrm{TiO}_{2}$ composite deposited from suspension methanesulfonate electrolytes allows one to achieve the result in accelerated tests in 325 hours, which exceeds the service life of the standard system by 16 times, although almost 2.5 times is inferior to the best result obtained for the transition layer formed on a titanium substrate.

Thus, using an Ebonex ${ }^{\circledR}$ with a platinumcontaining transition layer prepared by electrochemical-pyrolytic method as substrate allows obtaining anodes with $\mathrm{PbO}_{2}$ active layer. These anodes can be used under industrial operating conditions at current densities not exceeding $100 \mathrm{~mA} \mathrm{~cm}{ }^{-2}$. At the same time, the developed surface of Ebonex ${ }^{\circledast}$ does not allow it to be fully protected against possible passivation when the continuity of the active layer is violated, which creates problems for the reuse of the substrates of this type.

\section{Conclusions}

The use of the combined electrochemical- 
pyrolytic method consisting in the electrodeposition of a thin, non-continuous layer of platinum $\left(2 \mathrm{mg} \mathrm{cm}^{-2}\right)$ to the surface of the oxide $\left(\right.$ Ebonex $\left.^{\circledR}\right)$ substrate, followed by thermal treatment in the air atmosphere, results in the formation of compositional transition layers that are titanium oxide matrix in which the metal platinum is dispersed.

The chemical and phase composition of the resulting layer and its physicochemical properties depend on the temperature of treatment in the air. The semiconductor properties of the composite transition layers of $\mathrm{Ti}_{x} \mathrm{O}_{y} / \mathrm{Pt}$ are due to the formation of titanium(IV) oxide, which is n-type semiconductor.

The service life of DSA is largely determined by the nature of the substrate and the temperature of the transition layer formation. The maximum lifetime of the anodes was observed for substrates treated at $410^{\circ} \mathrm{C}$. At the same time, the maximum service life of anode at $500 \mathrm{~mA} \mathrm{~cm}{ }^{-2}$ was 325 hours with an active coating of $\mathrm{PbO}_{2}-\mathrm{TiO}_{2}$, which exceeds the standard $\mathrm{PbO}_{2}$ system by 16 times. However, due to lack of electrical conductivity, it is not recommended to use anodes with Ebonex ${ }^{\circledR}$ substrate at high anode current densities because of their heating and accelerated mechanical destruction of the active coating.

\section{REFERENCES}

1. Bunce N.J., Bejan D. Pollutants in water electrochemical remediation using Ebonex electrodes // Encyclopedia of Applied Electrochemistry. - New York: Springer.

2. Walsh F.C., Wills R.G.A. The continuing development of Magneli phase titanium sub-oxides and Ebonex ${ }^{\circledR}$ electrodes // Electrochim. Acta. - 2010. - Vol.55. - P.6342-6351.

3. Bejan D., Guinea E., Bunce N.J. On the nature of the hydroxyl radicals produced at boron-doped diamond and Ebonex® anodes // Electrochim. Acta. - 2012. - Vol.69. - P.275-281.

4. Farndon E.E., Pletcher D., Saraby-Reintjes A. The electrodeposition of platinum onto a conducting ceramic, Ebonex ${ }^{\circledast}$ // Electrochim. Acta. - 1997. - Vol.42. - P.1269-1279.

5. Characteristics of Pt thin films on the conducting ceramics $\mathrm{TiO}$ and Ebonex $\left(\mathrm{Ti}_{4} \mathrm{O}_{7}\right)$ as electrode materials / Park S.-Y., Mho S.-I., Chi E.O., Kwon Y.U., Park H.L. // Thin Solid Films. - 1995. - Vol.258. - P.5-9.

6. Rao C.R.K., Trivedi D.C. Chemical and electrochemical depositions of platinum group metals and their applications // Coord. Chem. Rev. - 2005. - Vol.249. - P.613-631.

7. Electrochemical behavior of platinized Ebonex ${ }^{\circledR}$ electrodes / Kasian O., Luk'yanenko T., Velichenko A., Amadelli R. // Int. J. Electrochem. Sci. - 2012. - Vol.7. - P.7915-7926.

8. Electrochemical properties of thermally treated platinized
Ebonex $^{\circledR}$ with low content of Pt / Kasian O.I., Luk’yanenko T.V., Demchenko P., Gladyshevskii R.E., Amadelli R., Velichenko A.B. // Electrochim. Acta. - 2013. - Vol.109. - P.630-637.

9. Mechanistic investigation of the conductive ceramic Ebonex $^{\circledR}$ as an anode material / D. Bejan, J.D. Malcolm, L. Morrison, N.J. Bunce // Electrochim. Acta. - 2009. - Vol.54. - P.5548-5556.

10. Co-Magneli phases electrocatalysts for hydrogen/oxygen evolution / Paunovic P., Popovski O., Fidancevska E., Ranguelov B., Stoevska Gogovska D., Dimitrov A.T., Jordanov S.H. // Int. J. Hydrogen Energy. - 2010. - Vol.35. - P.10073-10080.

11. Chen G., Betterton E.A., Arnold R.G. Electrolytic oxidation of trichloroethylene using a ceramic anode // J. Appl. Electrochem. - 1999. - Vol.29. - P.961-970.

12. Synthesis and characterization of hollandite-type material intended for the specific containment of radioactive cesium / Leinekugel-le-Cocq A.Y., Deniard P., Jobic S., Cerny R., Bart F., Emerich H. // J. Solid State Chem. - 2006. - Vol.179. - P.3196-3208.

13. Walsh F.C., Ponce de Leon C. Versatile electrochemical coatings and surface layers from methanesulfonic acid // Surf. Coat. Technol. - 2014. - Vol.259. - P.676-697.

14. Electrodeposition $\mathrm{PbO}_{2}-\mathrm{TiO}_{2}$ and $\mathrm{PbO}_{2}-\mathrm{ZrO}_{2}$ and its physicochemical properties / Velichenko A.B., Knysh V.A., Luk'yanenko T.V., Velichenko Yu.A., Devilliers D. // Mater. Chem. Phys. - 2012. - Vol.131. - P.686-693.

15. Dimensionally stable $\mathrm{PbO}_{2}$-based anodes / T. Luk'yanenko, V. Knysh, O. Shmychkova, A. Velichenko // Voprosy Khimii i Khimicheskoi Tekhnologii. - 2017. - No. 1. P.11-17.

Received 27.06.2019

\section{ДИЗАЙН І ВЛАСТИВОСТІ МАЛОЗНОШУВАНИХ АНОДІВ 3 ВИКОРИСТАННЯМ ЕВОNЕХ॰ ЯК КОЛЕКТОРА СТРУМУ}

\section{Т. Лук'яненко, О. Шмичкова, В. Книш, О. Веліченко}

Керамічні матеріали, що складаються з фаз Магнелі («субоксиди» Титану, що мають загальну формулу $T_{n} O_{2 n-l}$, де $n=4-10)$, відомі під торговою маркою Еьопех ${ }^{\circledast}$, використовувалися як колектори струму для конструювання малозношуваних анодів. Перед осадженням фінішного покриття електрохімічно-піролітичним методом створювали безперервний платиновий перехідний шар (2 мг Pt на $\left.\mathrm{cm}^{2}\right)$. Досліджено хімічний і фазовий склад одержуваного шару та його фізико-хімічні властивості. Згідно з отриманими даними, основною фазою комериійного Еbопех ${ }^{\circledast} \in \mathrm{Ti}_{6} \mathrm{O}_{11}$. Під час термічного оброблення система починає добирати Оксиген за рахунок окиснення субоксидів киснем повітря і вже за $230^{\circ} \mathrm{C}$ з'являється одна з фаз голандит, який за подальщої термічної обробки розщеплюється на дві фази $-\mathrm{Ti}_{5} \mathrm{O}_{9}$ i $\mathrm{TiO}_{2}$. За подальшого підвищення температури, перетворення системи триває $i$ за $310^{\circ} \mathrm{C}$ замість $\mathrm{Ti}_{5} \mathrm{O}_{9} 3$ 'являється нова фаза Титан оксиду. Ця фаза була ідентифікована вперше. 3 a $410^{\circ} \mathrm{C}$ кількість Оксигену в системі зростає, що приводить до появи $\mathrm{Ti}_{2}$ у вигляді рутилу. Показано, що термін служкби малозношуваних анодів багато в чому визначається природою підкладки і температурою утворення 
перехідного шару. Максимальний час експлуатації анодів спостерігався для колекторів струму, термооброблених за $410^{\circ} \mathrm{C}$. Максимальний термін служби анода за $500 \mathrm{MA} \mathrm{cm}^{-2}$ склав 325 год з активним покриттям $\mathrm{PbO}_{2}-\mathrm{TiO}_{2}$, що в 16 разів перевищує термін експлуатації $\mathrm{PbO}_{2}$, отриманого традиційним способом.

Ключові слова: Ebonex ${ }^{\circledR}$, підкладка, перехідний шар, малозношувані аноди, термін експлуатації.

\section{DESIGN AND PROPERTIES OF DIMENSIONALLY STABLE ANODES ON EBONEX ${ }^{\bullet}$ SUBSTRATE}

\section{T. Luk'yanenko, O. Shmychkova, V. Knysh, A. Velichenko * Ukrainian State University of Chemical Technology, Dnipro, Ukraine}

*e-mail: velichenko@ukr.net

Ceramic materials consisting of Magneli phases (titanium «suboxides» and having the general formula $\mathrm{Ti}_{n} \mathrm{O}_{2 n-1}$, where $n=4-$ 10), commercially recognized under the Ebonex ${ }^{\circledR}$ trade name, were used as substrates for designing of dimensionally stable anodes. The non-continuous platinum transition layer (2 $\mathrm{mg} P t$ per $\mathrm{cm}^{2}$ ) was formed before deposition of the resulting coating by electrochemicalpyrolytic method. The chemical and phase composition of the resulting layer and its physicochemical properties were investigated. According to the data obtained, the main phase of the commercial Ebonex ${ }^{\otimes}$ is $\mathrm{Ti}_{6} \mathrm{O}_{11}$. The system begins to collect oxygen during the thermal treatment due to oxidation of the suboxides with the air oxygen. Hollandite is one of the phases appeared already at $230^{\circ} \mathrm{C}$, it splits into two phases, $\mathrm{Ti}_{5} \mathrm{O}_{9}$ and $\mathrm{TiO}_{2}$, during the treatment. The transformation of the system continues with a subsequent increase in the temperature and a new phase of titanium oxide appears at $310^{\circ} \mathrm{C}$ instead of $\mathrm{Ti}_{5} \mathrm{O}_{9}$. This phase was identified for the first time. The amount of oxygen in the system increases at $410^{\circ} \mathrm{C}$, which leads to the additional appearance of $\mathrm{TiO}_{2}$ in the form of rutile. It has been shown that the service life of dimensionally stable anodes is largely determined by the nature of the substrate and the temperature of the formation of a transition layer. The maximum lifetime of the anodes was observed for the substrates treated at $410^{\circ} \mathrm{C}$. At the same time, the maximum service life of the anode at $500 \mathrm{~mA} \mathrm{~cm} \mathrm{~cm}^{-2}$ was 325 hours with an active coating of $\mathrm{PbO}_{2}-\mathrm{TiO}_{2}$, which exceeds the common $\mathrm{PbO}_{2}$ system by 16 times.

Keywords: Ebonex ${ }^{\circledR}$; substrate; transition layer; dimensionally stable anodes; service life.

\section{REFERENCES}

1. Bunce N.J., Bejan D., Pollutants in water electrochemical remediation using Ebonex electrodes. In: Kreysa G., Ota K., Savinell R.F. (eds.). Encyclopedia of Applied Electrochemistry. Springer, New York, NY.

2. Walsh F.C., Wills R.G.A. The continuing development of Magneli phase titanium sub-oxides and Ebonex ${ }^{\circledR}$ electrodes. Electrochimica Acta, 2010, vol. 55, pp. 6342-6351.

3. Bejan D., Guinea E., Bunce N.J. On the nature of the hydroxyl radicals produced at boron-doped diamond and Ebonex ${ }^{\circledR}$ anodes. Electrochimica Acta, 2012, vol. 69, pp. 275-281.
4. Farndon E.E., Pletcher D., Saraby-Reintjes A. The electrodeposition of platinum onto a conducting ceramic, Ebonex ${ }^{\circledR}$. Electrochimica Acta, 1997, vol. 42, pp. 1269-1279.

5. Park S.Y., Mho S.I., Chi E.O., Kwon Y.U., Park H.L. Characteristics of $\mathrm{Pt}$ thin films on the conducting ceramics TiO and Ebonex $\left(\mathrm{Ti}_{4} \mathrm{O}_{7}\right)$ as electrode materials. Thin Solid Films, 1995, vol. 258, pp. 5-9.

6. Rao C.R.K., Trivedi D.C. Chemical and electrochemical depositions of platinum group metals and their applications. Coordination Chemistry Reviews, 2005, vol. 249, pp. 613-631.

7. Kasian O., Luk'yanenko T., Velichenko A., Amadelli R Electrochemical behavior of platinized Ebonex ${ }^{\circledR}$ electrodes. International Journal of Electrochemical Science, 2012, vol. 7, pp. 7915-7926.

8. Kasian O.I., Luk’yanenko T.V., Demchenko P., Gladyshevskii R.E., Amadelli R., Velichenko A.B. Electrochemical properties of thermally treated platinized Ebonex ${ }^{\circledR}$ with low content of Pt. Electrochimica Acta, 2013, vol. 109, pp. 630-637.

9. Bejan D., Malcolm J.D., Morrison L., Bunce N.J. Mechanistic investigation of the conductive ceramic Ebonex ${ }^{\circledR}$ as an anode material. Electrochimica Acta, 2009, vol. 54, pp. 55485556.

10. Paunovic P., Popovski O., Fidancevska E., Ranguelov B., Stoevska Gogovska D., Dimitrov A.T., Jordanov S.H. Co-Magneli phases electrocatalysts for hydrogen/oxygen evolution. International Journal of Hydrogen Energy, 2010, vol. 35, pp. 1007310080 .

11. Chen G., Betterton E.A., Arnold R.G. Electrolytic oxidation of trichloroethylene using a ceramic anode. Journal of Applied Electrochemistry, 1999, vol. 29, pp. 961-970.

12. Leinekugel-le-Cocq A.Y., Deniard P., Jobic S., Cerny R., Bart F., Emerich H. Synthesis and characterization of hollanditetype material intended for the specific containment of radioactive cesium. Journal of Solid State Chemistry, 2006, vol. 179, pp. 31963208 .

13. Walsh F.C., Ponce de Leon C. Versatile electrochemical coatings and surface layers from methanesulfonic acid. Surface and Coatings Technology, 2014, vol. 259, pp. 676-697.

14. Velichenko A.B., Knysh V.A., Luk'yanenko T.V., Velichenko Yu.A., Devilliers D. Electrodeposition $\mathrm{PbO}_{2}-\mathrm{TiO}_{2}$ and $\mathrm{PbO}_{2}-\mathrm{ZrO}_{2}$ and its physicochemical properties. Materials Chemistry and Physics, 2012, vol. 131, pp. 686-693.

15. Luk'yanenko T., Knysh V., Shmychkova O., Velichenko A. Maloznoshuvanni anody $\mathrm{z}$ aktyvnym sharom na osnovi $\mathrm{PbO}_{2}$ [Dimensionally stable $\mathrm{PbO}_{2}$-based anodes]. Voprosy Khimii $i$ Khimicheskoi Tekhnologii, 2017, no. 1, pp. 11-17. (in Ukrainian). 